\title{
PERAN TABAYYUN SEBAGAI CERMINAN SIKAP KAUM MUKMININ DALAM MODEL MATEMATIKA PENYEBARAN RUMOR MELALUI JEJARING SOSIAL DARING
}

\author{
Nailul Izzati ${ }^{*}$, Silmi Kaaffah ${ }^{2}$ \\ ${ }^{1}$ Fakultas Teknik, Universitas Hasyim Asy'ari \\ ${ }^{2}$ Fakultas Bahasa Arab, International Islamic University of Islamabad \\ Email: nailulizzati@unhasy.ac.id
}

\begin{abstract}
ABSTRAK
Platform digital dan media sosial kini menjadi salah satu alat komunikasi dan sumber informasi. Perkembangan teknologi memberikan dampak positif sekaligus negatif bagi penggunanya. Derasnya arus informasi mengharuskan masyarakat memiliki filter yang kuat dan sikap yang bijak dalam menanggapi sebuah berita, terutama yang masih belum jelas kebenarannya. Suatu rumor dapat menjadi viral berkat komunikasi melalui jejaring sosial daring. Penelitian ini membahas model matematika untuk mengilustrasikan dinamika yang terjadi dalam jejaring sosial daring saat suatu rumor berhembus. Model matematika yang dimaksudkan mempertimbangkan sikap ideal kaum Mukminin berdasarkan AlQur'an dan Hadits, termasuk di antaranya adalah anjuran tabayyun serta larangan berprasangka, tajassus, dan ghibah. Model matematika yang diperoleh kemudian dianalisis titik kesetimbangannya dan disimulasikan menggunakan Metode Runge- Kutta. Hasil simulasi numerik menunjukkan bahwa penerapan sikap tabayyun dalam menanggapi suatu berita serta menahan diri untuk tidak berprasangka, tajassus, dan ghibah dalam model, dapat menekan laju penyebaran rumor dalam jejaring sosial daring.
\end{abstract}

Kata kunci: Model Matematika, Jejaring Sosial Daring, Rumor, Tabayyun.

\section{A.PENDAHULUAN}

Di era digital dan media sosial, hampir setiap orang dapat mengakses berbagai informasi dengan mudah dan cepat. Interaksi dan komunikasi tidak lagi hanya dilakukan dengan cara konvensional melalui tatap muka, surat ataupun telepon, tetapi juga bisa secara daring melalui berbagai macam perangkat dan aplikasi. Era digital dan media sosial memberikan wadah bagi berkembangnya bidang ekonomi, seni, sosial, budaya, pendidikan, ilmu pengetahuan, dan lain sebagainya, tak terkecuali bidang dakwah. Berbagai macam platform dan aplikasi dengan berbagai fitur ditawarkan bagi pengguna teknologi digital dan media sosial. Pesatnya perkembangan teknologi berbanding lurus dengan banyaknya informasi 
yang beredar di masyarakat, hal ini sering disebut dengan banjir informasi. Banjir informasi di era digital tentunya perlu disikapi dengan bijaksana dalam menanggapi sebuah informasi atau berita. Saat ini, sebuah berita dapat dengan mudah tersebar, tanpa diketahui tingkat kebenaran dari berita tersebut. Tanpa kebijaksanaan dan pemahaman, masyarakat bisa menjadi pelaku ataupun korban penyebaran berita bohong.

Bagaikan virus yang begitu cepat penyebarannya, suatu berita bisa menjadi viral dan membuat heboh. Bentuk berita yang tidak jelas kebenarannya, bisa berupa gosip, hoax, dan lain sebagainya, secara umum dapat disebut sebagai rumor, atau desas-desus. Menurut kamus, gosip diartikan sebagai obrolan tentang orang-orang lain, cerita negatif tentang seseorang, atau pergunjingan. ${ }^{1}$ Sedangkan hoax adalah berita bohong atau kabar burung. ${ }^{2}$ Hoax yang beredar dapat berupa berita politik, kesehatan, hiburan, bahkan ilmu pengetahuan. Dalam upaya pencegahan penyebaran hoax, Kementerian Komunikasi dan Informatika memiliki website untuk mengklarifikasi hoax yang beredar di masyarakat. Namun tentu saja ini tidak cukup untuk membendung derasnya arus informasi di masyarakat, apalagi ditambah dengan adanya rasa ketidakpercayaan dari sebagian masyarakat kepada pemerintah. Tetap, ujung tombak tersebarnya sebuah rumor adalah masyarakat.

Dalam penelitian Adhiarso dkk tentang pemberitaan hoax di media daring yang ditinjau dari konstruksi berita dan respon netizen, disebutkan bahwa respon netizen berpengaruh positif dan signifikan terhadap pemberitaan hoax di media daring. Dengan kata lain, banyaknya netizen yang merespon suatu hoax berbanding lurus dengan peredaran hoax di media daring. Semakin banyak yang merespon maka semakin luas dan liar pemberitaan hoax tersebut [1].

Dinamika penyebaran rumor dapat dibahas dalam sudut pandang matematika. Penelitian tentang hal tersebut di antaranya dibahas oleh Dhar dkk [2]. Dalam penelitiannya, Dhar dkk membangun sistem persamaan diferensial berupa model SEI yang diadopsi dari model penyebaran penyakit dengan mengasumsikan rumor sebagai suatu penyakit yang bisa menyebar. Selain

\footnotetext{
${ }^{1}$ https://kbbi.web.id/gosip.html. Diakses pada 16 April 2020, pukul 23.38 WIB.

2 John M. Echols dan Hassan Shadily. 2005. Kamus Inggris Indonesia: An English-Indonesian Dictionary. Jakarta: PT Gramedia.
} 
Dhar dkk, terdapat peneliti lain yang membahas model serupa, seperti Xia dkk [3], Zhu dan Wang [4], Hu dkk [5], Ningsih dkk [6], dan lain sebagainya. Xia dkk membahas modifikasi model SEIR dengan mekanisme keraguan yang dipengaruhi oleh daya tarik dan ketidakjelasan dari rumor yang beredar. Zhu dan Wang memodifikasi model SIR untuk mengetahui penyebaran rumor jejaring sosial yang kompleks dengan intervensi kegaduhan. Hu dkk juga memodelkan rumor sebagai penyakit yang dapat menyebar. Model matematika yang ditulis oleh $\mathrm{Hu}$ dkk mempertimbangkan adanya proporsi orang bijak dalam sebuah populasi dan pengaruhnya terhadap laju penyebaran rumor. Sedangkan Ningsih dkk melakukan pengendalian optimal dari model yang ditulis oleh Dhar dkk. Penerapan asumsi dan sudut pandang yang berbeda dalam melihat penyebaran rumor dapat menghasilkan model matematika yang berbeda.

Al-Qur'an dan Hadits sebagai pedoman hidup umat Islam, punya panduan dalam menyikapi suatu berita, utamanya yang bersifat hoax maupun gosip. Bergosip merupakan tindakan yang dilarang dalam agama Islam. Dalam Islam, dikenal pula sikap yang disebut tabayyun. Berdasarkan dalil yang ada pada Al- Qur'an dan Hadits, serta terinspirasi dari penelitian terdahulu, penelitian ini membahas model matematika tentang penyebaran rumor melalui jejaring sosial daring serta kaitannya dengan sikap yang dianjurkan oleh Al-Qur'an dan Hadits dalam menanggapi suatu berita

\section{B. KAJIAN TAFSIR}

Dalam Bahasa Arab, istilah berita dinyatakan dengan lafadz berita, kabar, informasi, pesan, cerita, kisah. ${ }^{34}$ Lafadz نبأ disebutkan sebanyak 68 kali dalam al-Quran dalam 63 ayat dalam berbagai bentuk. ${ }^{5}$ Pada bagian ini, ayat Al-Qur'an yang dikaji sehubungan dengan kaitannya dengan penyebaran berita bohong adalah QS. Al-Hujurat ayat 6. Dalam ayat tersebut Allah SWT berfirman,

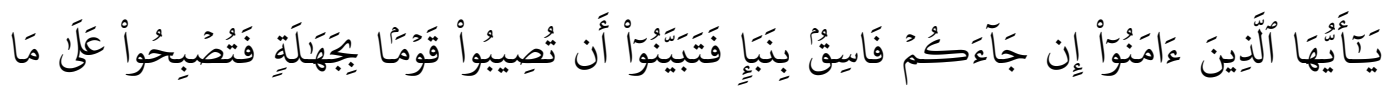

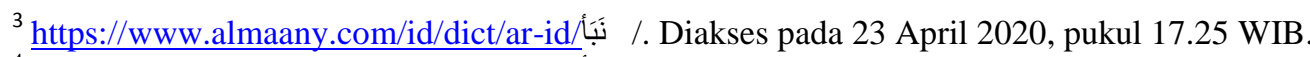

${ }_{4}^{4}$ https://www.almaany.com/id/dict/ar-id/4ن. Diakses pada 23 April 2020, pukul 18.53 WIB

${ }^{5}$ Ditelusuri menggunakan software Zekr (lihat http://zekr.org).
} 


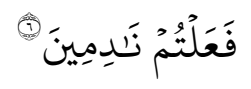

Artinya: "Hai orang-orang yang beriman, jika datang kepadamu orang fasik membawa suatu berita, maka periksalah dengan teliti agar kamu tidak menimpakan suatu musibah kepada suatu kaum tanpa mengetahui keadaannya yang menyebabkan kamu menyesal atas perbuatanmu itu."

Menurut Sayyid Quthb, ayat ini menerangkan kepada kaum mukminin bagaimana mereka menanggapi suatu berita yang mereka terima. Seruan ini menegaskan pentingnya perujukan kepada sumber berita (tabayyun). Allah memfokuskan orang fasik karena mereka dicurigai sebagai sumber kebohongan. Serta bertujuan agar keraguan tidak menyebar di kalangan kaum muslimin karena berita yang disebarkan oleh setiap individunya.

Dalam memutuskan untuk mengambil/menolak suatu berita, pada prinsipnya hendaknya setiap individu kaum muslimin menjadi sumber berita benar, terpercaya, dan dapat dijadikan pegangan. Sedangkan orang fasik adalah sumber keraguan. Kaum muslimin jangan tergesa-gesa bertindak berdasarkan berita dari orang fasik. Ketergesa-gesaan dapat mengakibatkan seseorang bertindak zalim kepada suatu kaum sehingga menyesal karena telah melakukan perbuatan yang dimurkai oleh Allah serta tidak mempertahankan kebenaran dan keadilan. Dalam suatu riwayat Rasullah SAW bersabda

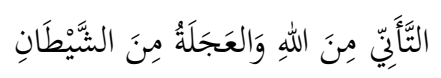

"Kehati-hatian adalah dari Allah, sedangkan ketergesa-gesaan adalah dari setan."

QS Al-Hujurat ayat 6 ini bermakna general, yakni mengandung prinsip selektif dan hati-hati terhadap informasi dari orang fasik. Sedangkan berita dari orang sholeh dapat diambil, sebab dialah pangkal di dalam kelompok mukmin. Mengambil berita dari orang sholeh merupakan bagian dari manhaj kehati-hatian, sebab dia merupakan salah satu sumber berita. Islam menginginkan kehidupan berjalan di jalur alamiah. Islam hanya memasang pagar dan jaminan demi memelihara kehidupan, bukan menelantarkannya. Inilah model kebebasan

${ }^{6}$ Surat Al-Hujurat: 6 
dalam mengambil berita dari sumbernya, yang disertai dengan pengecualian. ${ }^{7}$

Menurut HAMKA, QS Al-Hujurat ayat 6 memberikan larangan keras untuk langsung percaya kepada berita yang dibawa oleh orang fasik, memburukkan seseorang atau suatu kaum. Suatu perkara tidak boleh langsung disetujui maupun ditolak, tetapi harus diselidiki terlebih dahulu dengan seksama tentang benar atau tidaknya. Seorang yang fasik dapat diartikan sebagai seorang pembohong, bisa juga diartikan sebagai orang yang tidak segan-segan menyatakan suatu perbuatan dosa. Ayat ini menjadi suatu pedoman bagi kaum Muslimin bahwa mereka tidak boleh cepat dalam menerima suatu berita, atau isu, atau gosip, atau fitnah yang dibuatbuat, sehingga masyarakat menjadi heboh. Kabar yang demikian tidak jelas ujung pangkalnya, dan kebanyakan orang dengan cepat menerimanya tanpa berpikir panjang atas kebenarannya. Apabila Agama Islam ingin dijadikan sebagai pedoman hidup kaum Muslimin, maka ayat ini patut dijadikan pegangan saat mendengar gosip yang beredar di masyarakat. ${ }^{8}$

Dalil lain yang berhubungan dengan beredarnya gosip adalah QS. AlHujurat ayat 12. Dalam ayat tersebut Allah SWT berfirman,

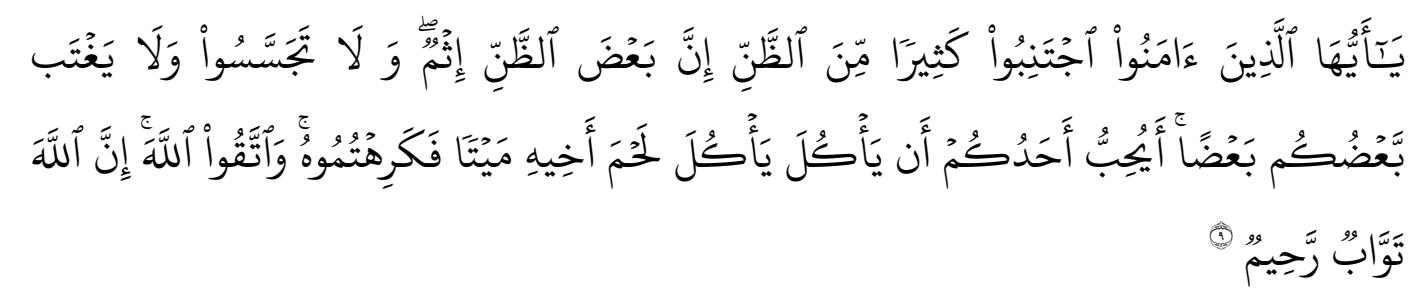

Artinya: "Wahai orang-orang beriman! Jauhilah banyak prasangka, sesungguhnya sebagian prasangka itu dosa dan janganlah kamu mencari-cari kesalahan orang lain dan janganlah ada di antara kamu menggunjing sebagian lain. Apakah ada diantara kamu yang suka memakan daging saudaranya yang sudah mati? Tentu kamu merasa jijik. Dan bertaqwalah kepada Allah, sesungguhnya Allah Maha Penerima taubat lagi Maha Penyayang."

\footnotetext{
${ }^{7}$ Sayyid Quthb. 2004. Tafsir Fi Zhilalil Qur'an Di Bawah Naungan Al-Qur'an, Jilid 10. Jakarta: Gema Insani Press. Hal 413-415

${ }^{8}$ HAMKA. 2008. Tafsir Al-Azhar, Juz XXV-XXVI. Jakarta: PT Pustaka Panjimas. Hal 191-193.

${ }^{9}$ Surat Al-Hujurat: 12
} 
Dalam QS. Al-Hujurat ayat 12, terdapat tiga perkara yang harus dihindari seorang mukmin terhadap mukmin lainnya, yaitu:

1. الظَّنِّ yaitu berprasangka kepada sesama mukmin, prasangka yang dimaksudkan di dalam ayat ini adalah prasangka buruk atau berprasangka yang berlebihan kepada mukmin lainnya. Prasangka dalam syari'at ada dua macam: Pertama, prasangka baik (yang terpuji), "Mahmud", atau dalam kebaikan yang dapat menyelamatkan seorang mukmin dalam urusan agama. Kedua, adalah sebaliknya yaitu prasangka buruk (yang tercela), "Madzmum", atau dalam keburukan. ${ }^{10}$ Adapun prasangka baik diperbolehkan kepada mukmin lainnya, ${ }^{11}$ sebagaimana yang tertera di dalam firman Allah:

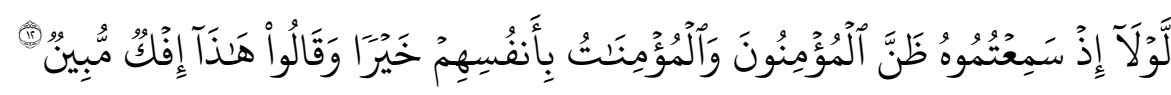

Artinya: Mengapa orang-orang mukmin dan mukminat tidak berbaik sangka terhadap diri mereka sendiri, ketika kamu mendengar berita bohong itu dan berkata: "ini adalah (suatu berita) bohong yang nyata

Kata الظَّنِّ dapat diartikan juga sebagai tuduhan kepada mukmin lainnya, yang belum jelas hakikat yang sebenarnya. ${ }^{13}$

2. Tajassus atau memata-matai atau mencari kesalahan mukmin lainnya, yang mana ia telah berusaha menutupinya. ${ }^{14}$ Dalam hadits Nabi SAW disebutkan:

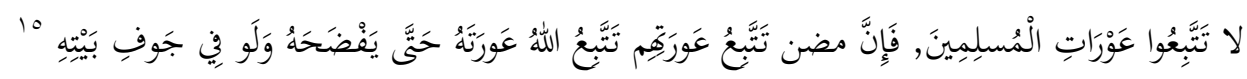

Artinya: "Janganlah kau mengikuti/mengejar aurat/kekurangan para muslimin, Sesungguhnya barang siapa mengikuti aurat muslimin, maka Allah SWT akan mengikuti aurat mereka/pelakunya kemudian membongkarnya meskipun aurat tersebut berada di dalam lubang terkecil dalam rumahnya

Tajassus harus dihindari seorang muslim karena dapat merusak silaturahim sesama muslim, juga dapat menghancurkan harga diri seorang

\footnotetext{
10 Al-Qurthubi, Aljami' Liahkamil Qur'an, Darul Kutub Al-Mishriyah, Kairo, 1384 H/1964 M, 16/332.

${ }^{11}$ Athobari, Jami'ul Bayan fi Takwilil Qur'an, Muassatur Risalah, 1420 H/2000 M, 22/304

${ }^{12}$ Surat An-Nur: 12

13 Al-Qurthubi, Aljami’ Liahkamil Qur'an, Darul Kutub Al-Mishriyah, Kairo, 1384 H/1964 M, 16/331.

${ }^{14} \mathrm{Abu}$ 'Ali Athorbusiy, Majma'al Bayan fi Tafsiril Qur'an, Darul 'Ilmi, Beirut, 1427 H/22006 M, 9/174-175.

${ }^{15}$ Al-Baidlowi, Anwaru Tanzil wa Asroru Ta’wil, Darul Ihya’i Turots, Beirut, 1418 H, 5/136
} 
muslim. Dan wajib bagi seorang muslim menutupi kekurangan/aib saudaranya. ${ }^{16}$

3. Perkara terakhir (dalam QS Al-Hujurat ayat 12) yang harus dihindari mukmin adalah ghibah, yaitu menggunjing atau menyebutkan aib orang lain (seorang mukmin) ketika ia tidak ada, yang mana ia sendiri menutupi aib tersebut dan ia enggan mendengarnya, seperti yang disebutkan dalam hadits Nabi SAW:

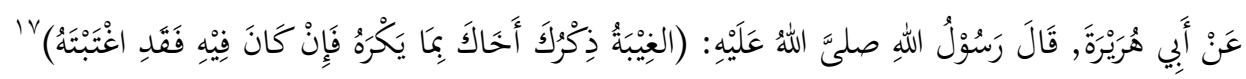

Yang artinya: Dari Abu Hurairah, Rasulullah SAW bersabda: "Ghibah adalah menyebutkan hal yang dibenci oleh saudaramu, jika kamu menyebutkannya (kepada orang lain) maka kamu telah menggunjingnya”.

Ghibah juga dapat diartikan sebagai menyebutkan aib orang lain yang tidak mengandung hikmah di dalamnya ketika ia tidak ada. ${ }^{18}$ Disebutkan

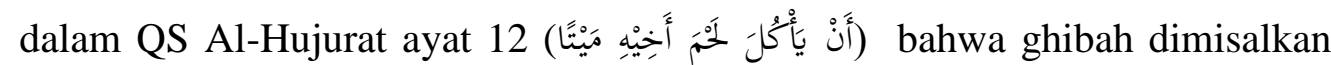
dengan memakan bangkai mayat sauadara sendiri, sungguh merupakan perbuatan yang menjijikan, keji dan hina.

Banyaka hadits Nabi SAW yang menerangkan tentang buruknya ghibah kepada sesame muslim dan kejamnya hukuman terhadap pelakunya, seperti:

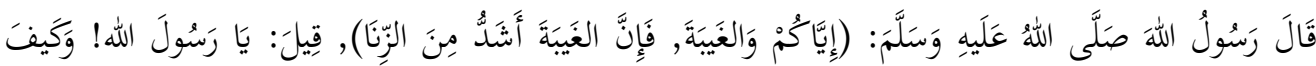

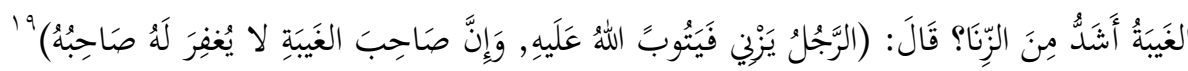

Artinya: Rasulullah SAW bersabda: "Jauhkanlah dirimu dari ghibah, sesungguhnya ghibah lebih buruk (keji) dari zina" seseorang bertanya: Ya Rasulullah SAW! Bagaimana bisa ghibah lebih buruk dari zina?, Rasulullah SAW berkata: "Seorang pria jika berzina kemudian ia bertaubat maka Allah mengampuninya (menerima taubatnya), namun seseorang yang

\footnotetext{
${ }^{16}$ Ibn Katsir, Tafsirul Qur'anil Adzim, Darut Thoyyibah, 1420 H/1999 M, 7/353-354

${ }^{17}$ Ibrahim bin Ishaq, Ghoribul Hadits, Jami’atul Ummul Quro', Mekkah, 1405 H, 2/612

${ }^{18}$ Al-Faroby, Ashohah Tajul Lughoh Tajul 'Arobiyah, Darul 'Ilmi Lilmalayin, Beirut, cetakan ke 4, $1407 \mathrm{H} / 1987 \mathrm{M}, 1 / 196$

${ }^{19} \mathrm{Abu}$ Bakar Al-Malikiy, Al-Majalisah wa Jawahirul 'Ilmi, Jam'iyat Tarbiyah AlIslamiyah, Bahrain, 1419 H, 8/272
} 
bergunjing (ghibah) tidak akan diampuni dosanya sampai orang yang ia gunjingkan memaafkannya".

\section{METODE PENELITIAN}

Hal pertama yang dilakukan dalam penelitian ini adalah kajian tafsir yang berhubungan dengan berita bohong dan penyebarannya, dalam penelitian ini dikaji QS Al-Hujurat ayat 6 dan 12. Dari kajian tafsir yang dilakukan, diperoleh informasi tentang sumber berita benar dan berita bohong, serta sikap yang sesuai dengan sudut pandang Al-Qur'an dalam menanggapi suatu berita. Berdasarkan konsep tersebut, ditentukan variabel-variabel dan parameter-parameter yang bersesuaian dengan model matematika yang dimaksudkan.

Model matematika dalam penelitian ini adalah pengembangan dari model penyebaran rumor dalam jejaring sosial daring yang dibahas oleh Dhar dkk [2]. Dalam modelnya, Dhar dkk mempertimbangkan bahwa terdapat tiga tipe orang sehubungan dengan sikapnya dalam menerima berita dari media sosial, yakni non-adopter $(S)$, thinker $(E)$, dan adopter (I). Non-adopter sebagai subpopulasi susceptible (rentan rumor) adalah tipe user (pengguna media sosial) yang belum mengetahui informasi apapun terkait suatu berita yang tersebar. Sedangkan thinker sebagai subpopulasi exposed (terpapar rumor) adalah tipe user yang telah mendapatkan informasi tentang berita tersebut, namun mengambil waktu untuk berpikir sebelum merespon. Dan adopter sebagai subpopulasi infected (termakan rumor) adalah tipe user yang percaya rumor dan menyebarkannya. Diasumsikan bahwa adopter (I) yang telah mengetahui fakta sebenarnya dari berita yang tersebar bisa jadi diam saja atau tetap menyebarkan berita tersebut dalam interaksinya dengan subpopulasi non-adopter $(S)$ dan thinker $(E)$.

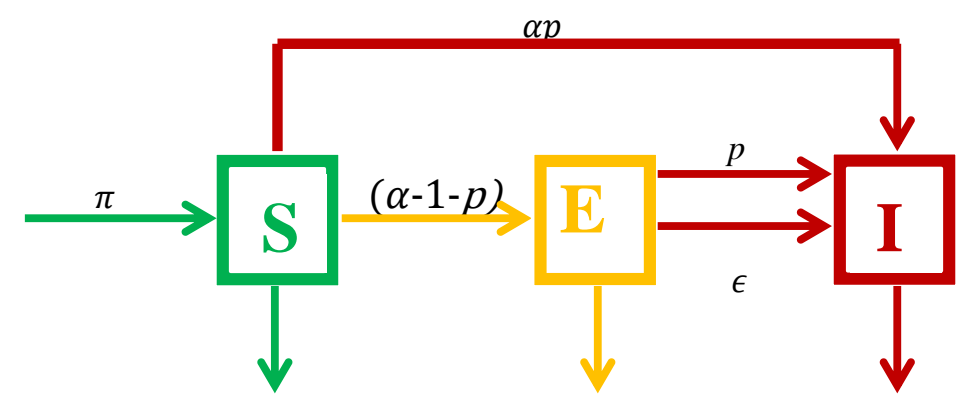

Gambar 1. Diagram Kompartemen Model Penyebaran Rumor pada Jejaring 


\section{Sosial Daring}

Model yang dibangun diilustrasikan dengan diagram kompartemen pada Gambar 1 dan secara matematis dinyatakan oleh sistem persamaan (1)-(3).

$$
\begin{aligned}
& \frac{d S}{d t}=\pi-\alpha \frac{S I}{N}-\theta_{1} S \\
& \frac{d E}{d t}=\alpha(1-p) \frac{S I}{N}-\rho \frac{E I}{N}-\left(\epsilon+\theta_{2}\right) E \\
& \frac{d I}{d t}=\alpha \mathrm{p} \frac{S I}{N}+\rho \frac{E I}{N}+\epsilon \mathrm{E}-\theta_{3} \mathrm{I}
\end{aligned}
$$

Dengan variabel dan parameter dalam sistem (1)-(3) adalah sebagai berikut:

$S$ : susceptible, yakni tipe non-adopter, sebagai subpopulasi yang rentan terhadap rumor,

$E$ : exposed, yakni tipe thinker, sebagai subpopulasi yang terpapar rumor, namun berpikir dahulu sebelum menyebarkan suatu berita,

I : infected, yakni tipe adopter, sebagai subpopulasi yang percaya rumor tanpa mengecek kebenarannya kemudian menyebarkannya,

$N$ : total populasi,

$\pi$ : recruitment rate, yaitu tingkat bergabungnya user baru dalam media sosial,

$\alpha$ : tingkat interaksi antara subpopulasi S dan I,

$p$ : probabilitas munculnya adopter baru (dari individu $\mathrm{S}$ ke I),

$(1-p)$ : proporsi transformasi dari individu non-adopter menjadi thinker (dari individu S menjadi E),

$\rho$ : tingkat interaksi antara subpopulasi E dan I,

$\epsilon$ : laju transformasi thinker menjadi adopter (dari individu E menjadi I),

$\theta_{1}$ : natural washout rate, yaitu tingkat anggota non-aktif dalam jejaring sosial, pada subpopulasi $\mathrm{S}$,

$\theta_{2}$ : natural washout rate pada subpopulasi $\mathrm{E}$,

$\theta_{3}$ : natural washout rate pada subpopulasi I.

Dalam menekan penyebaran rumor, Dhar dkk mempertimbangkan strategi pernyataan balasan (counter statement) dalam media sosial, sebagai tindakan 
perlawanan. Hal ini diilustrasikan dengan diagram kompartemen pada Gambar 2 dan dinyatakan oleh sistem persamaan (4)-(6), dengan parameter $c$ menyatakan probabilitas diterimanya pernyataan balasan dalam media sosial dan $\gamma$ merepresentasikan recovery rate dari subpopulasi adopter setelah menerima pernyataan balasan.ý

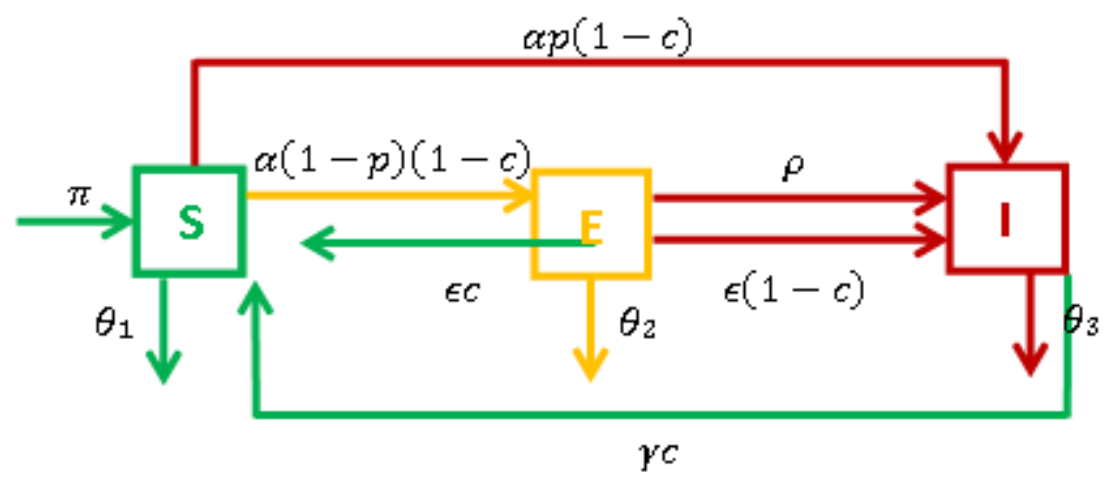

Gambar 2. Diagram Kompartemen Model Penyebaran Rumor pada Jejaring Sosial Daring dengan Pemberian Pernyataan Balasan

$$
\begin{aligned}
& \frac{d S}{d t}=\pi-\alpha(1-\mathrm{c}) \frac{S I}{N}+\epsilon c E+\gamma c I-\theta_{1} S \\
& \frac{d E}{d t}=\alpha(1-p)(1-\mathrm{c}) \frac{S I}{N}-\rho \frac{E I}{N}-\left(\epsilon+\theta_{2}\right) E \\
& \frac{d I}{d t}=\alpha \mathrm{p}(1-\mathrm{c}) \frac{S I}{N}+\rho \frac{E I}{N}+\epsilon y ́(1-\mathrm{c}) \mathrm{y} \mathrm{E}-\gamma c I-\theta_{3} \mathrm{I}
\end{aligned}
$$

Pengembangan yang dilakukan terhadap model adalah dengan mengubah asumsi dan sudut pandang, serta mempertimbangkan variabel atau parameter yang belum ada pada model acuan, sehingga sesuai dengan konsep tafsir QS. AlHujurat ayat 6 dan 12. Setelah model matematika hasil modifikasi terkonstruksi, dilakukan simulasi numerik menggunakan software Maple untuk mengetahui perilaku solusi sistem. Hasil simulasi kemudian diinterpretasikan dan diambil simpulan. Alur dari penelitian ini secara singkat dapat disajikan dengan Gambar 3. 


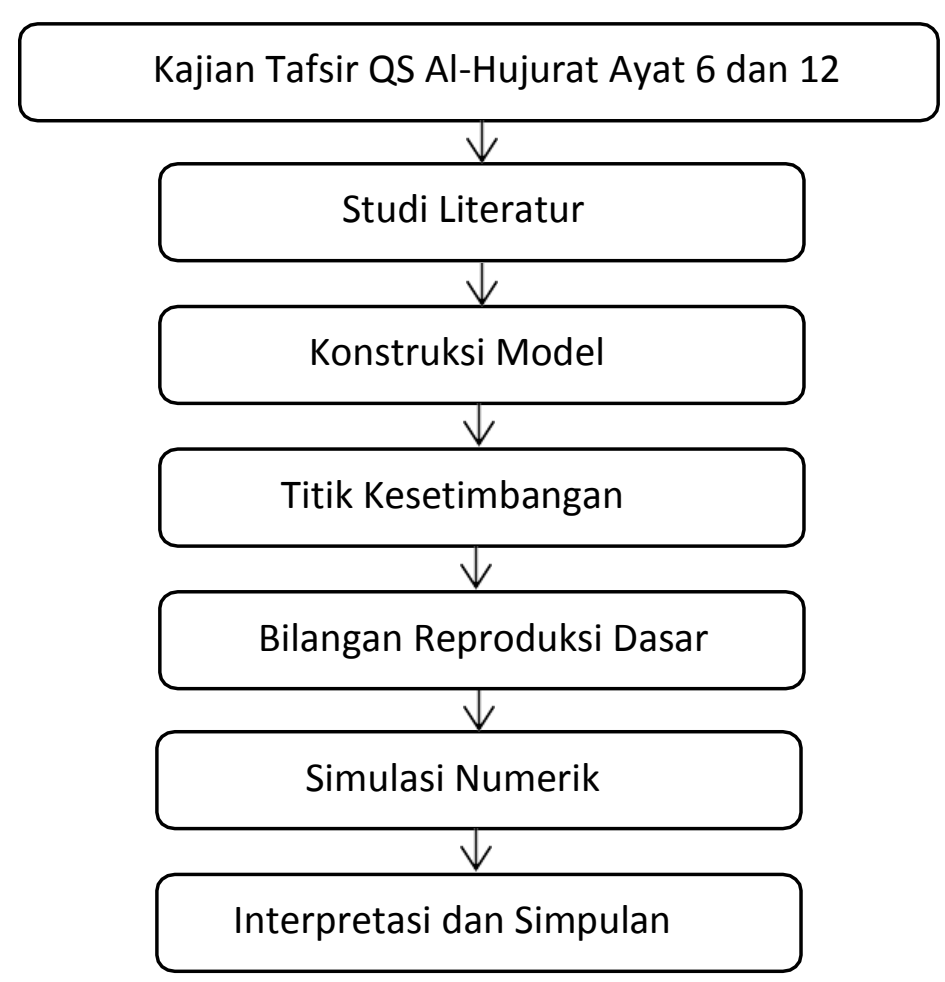

\section{Gambar 3. Diagram Alir Metode Penelitian}

\section{HASIL DAN PEMBAHASAN}

Pada bagian ini dibahas model matematika penyebaran rumor melalui jejaring sosial daring, meliputi konstruksi dan simulasi numeriknya.

\section{A. Kostruksi Model Matematika}

Dalam konstruksi model matematika penyebaran rumor, penelitian ini menerapkan asumsi dan batasan sebagai berikut:

a. Dalam suatu jejaring sosial daring, diasumsikan ada sebuah rumor yang beredar. Berdasarkan sikapnya dalam menanggapi rumor, pengguna media sosial (user) terbagi menjadi empat kelompok, yaitu non-adopter, thinker, adopter, dan verifier. Pengertian non-adopter, thinker, dan adopter, merujuk pada penelitian Dhar dkk [7]. Non-adopter sebagai kelompok rentan rumor, thinker sebagai kelompok terpapar, dan adopter sebagai kelompok yang termakan rumor. Sedangkan verifier adalah kelompok yang terbebas dari rumor.

b. Diasumsikan bahwa seseorang terbebas dari rumor apabila telah mengetahui fakta objektif atau kebenaran dari rumor yang beredar. Hal ini bisa diperoleh melalui proses verifikasi atau kroscek terhadap kebenaran 
suatu berita, yang dalam Islam dikenal dengan istilah tabayyun. Selain itu, diasumsikan pula bahwa seseorang dapat terbebas dari rumor apabila mampu menjauhi atau menahan diri dari prasangka, tajassus, dan ghibah.

c. Jumlah total user dipengaruhi oleh recruitment rate dan natural washout rate. Adanya recruitment atau pengguna baru dalam media sosial membuat total user bertambah. Sedangkan adanya natural washout, atau pengguna yang non-aktif pada media sosial, membuat total user berkurang. Diasumsikan bahwa natural washout rate pada keempat kelompok user adalah sama.

d. Penyebaran rumor terjadi ketika user yang belum mendengar rumor (nonadopter) berinteraksi dengan user yang telah termakan rumor (adopter). Setelah mendapatkan informasi mengenai rumor tersebut, nonadopter dapat bertransformasi menjadi thinker, atau adopter, atau verifier.

e. Non-adopter menjadi thinker apabila berpikir terlebih dahulu sebelum mempercayai dan menyebarkan rumor tersebut. Menjadi adopter apabila langsung percaya dan menyebarkannya. Dan menjadi verifier apabila mengecek kebenarannya (tabayyun), atau menahan diri untuk tidak berprasangka, tajassus, dan ghibah.

f. Thinker dapat bertransformasi menjadi adopter atau verifier. Thinker berubah menjadi adopter apabila setelah selang waktu tertentu percaya terhadap rumor kemudian menyebarkannya. Hal ini bisa terjadi atas dasar pemikirannya sendiri, maupun terpengaruh oleh adanya interaksi antara thinker dengan adopter. Thinker dimungkinkan berubah menjadi verifier apabila melakukan tabayyun atau menjauhi prasangka, tajassus dan ghibah.

Berdasarkan asumsi dan batasan yang dikonstruksi, diperoleh diagram kompartemen dari model matematika penyebaran rumor dalam jejaring sosial daring dengan penerapan sikap tabayyun dan pertahanan diri untuk tidak berprasangka, tajassus, dan ghibah. Diagram kompartemen model disajikan dalam Gambar 4. Secara matematis, model ini dinyatakan oleh sistem persamaan (7)-(10). 


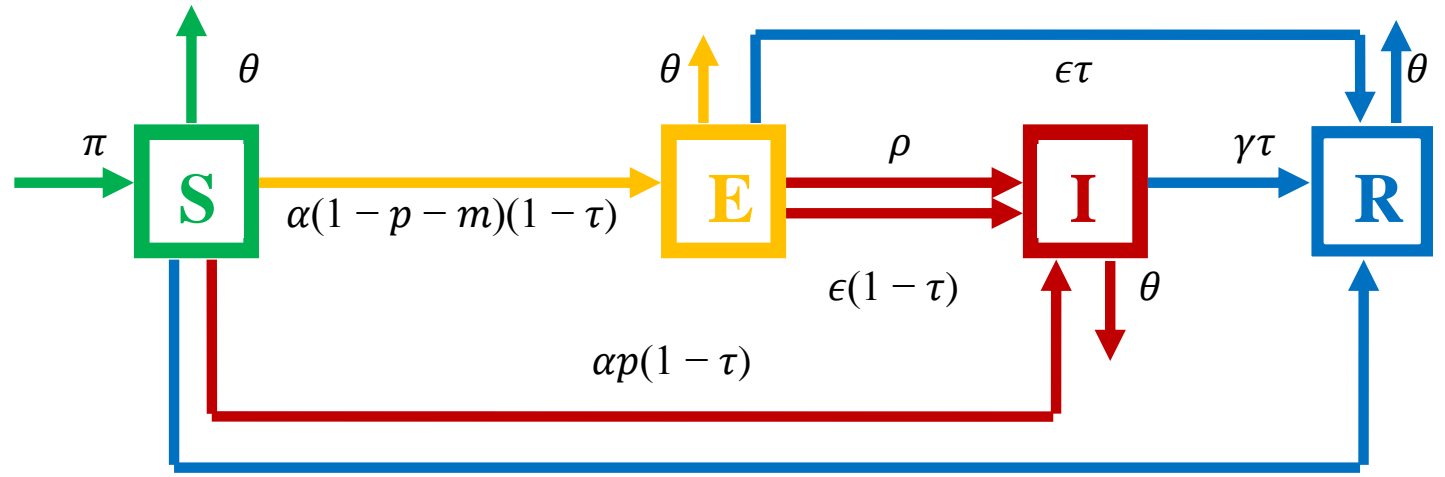

Gambar 4. Diagram Kompartemen Model Penyebaran Rumor Melalui Jejaring Sosial Daring dengan Pertimbangan Sikap Kaum Mukminin

$$
\begin{aligned}
& \frac{d S}{d t}=\pi N-\alpha(1-\tau) \frac{S I}{N}-\theta S \\
& \frac{d E}{d t}=\alpha(1-p-m)(1-\tau) \frac{S I}{N}-\rho \frac{E I}{N}-(\epsilon+\theta) E \\
& \frac{d I}{d t}=\alpha \mathrm{p}(1-\tau) \frac{S I}{N}+\rho \frac{E I}{N}+\epsilon(1-\tau) \mathrm{E}-\gamma c I-\theta \\
& \frac{d R}{d t}=\alpha \mathrm{m}(1-\tau) \frac{S I}{N}+\epsilon \tau E+\gamma \tau I-\theta R
\end{aligned}
$$

Variabel $R$ melambangkan kelompok verifier. Parameter $\tau$ merepresentasikan probabilitas diterapkannya sikap tabayyun dalam menyikapi rumor, $m$ adalah proporsi pengguna media sosial yang mampu menahan diri dari prasangka, tajassus, dan ghibah, sedangkan $\theta$ adalah natural washout rate. Semua variabel dan parameter dalam sistem bernilai lebih besar atau sama dengan nol.

Misalkan variabel non-dimensional $s=\frac{S}{N}, e=\frac{E}{N}, i=\frac{I}{N}$, dan $r=\frac{R}{N}$ maka sistem (7)-(10) dapat ditulis ulang sebagai sistem (11)-(14).

$$
\begin{aligned}
& \frac{d s}{d t}=\pi-\alpha(1-\tau) s i-\theta s \\
& \frac{d e}{d t}=\alpha(1-p-m)(1-\tau) s i-\rho e i-(\epsilon+\theta) e
\end{aligned}
$$




$$
\begin{aligned}
& \frac{d i}{d t}=\alpha \mathrm{p}(1-\tau) s i+\rho e i+\epsilon(1-\tau) e-\gamma \tau i-\theta i \\
& \frac{d r}{d t}=\alpha \mathrm{m}(1-\tau) s i+\epsilon \tau e+\gamma \tau i-\theta r
\end{aligned}
$$

B. Keadaan setimbang

Titik kesetimbangan sistem perlu ditentukan untuk mengetahui dinamika yang terjadi dalam model. Titik kesetimbangan sistem (11)-(14) diperoleh dengan menyelesaikan sistem $\frac{d s}{d t}=0, \frac{d e}{d t}=0, \frac{d i}{d t}=0, \frac{d r}{d t}=$ 0 Apabila tidak ada adopter atau pengguna media sosial yang termakan rumor $(i=0)$, maka diperoleh titik kesetimbangan bebas rumor, $E_{o}=$ $\left(\frac{\pi}{\theta}, 0,0,0\right)$. Sedangkan apabila terdapat pengguna media sosial yang termakan rumor dan menyebarkannya $(i \neq 0)$, maka diperoleh titik

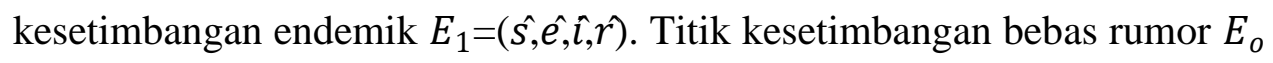
selalu feasible karena semua parameter bernilai positif. Sedangkan titik kesetimbangan endemik $E_{1}$ belum tentu feasible. Titik kesetimbangan $E_{1}$ terlalu panjang untuk ditemukan secara perhitungan aljabar. Oleh karena itu, analisis lebih lanjut tentang titik kesetimbangan $E_{1}$ dilakukan melalui perhitungan numerik

C. Bilangan Reproduksi Dasar

Bilangan reproduksi dasar $\left(R_{o}\right)$ mendefinisikan jumlah kasus sekunder yang dihasilkan apabila terdapat sebuah rumor yang berhembus dalam kelompok non-adopter. Bilangan ini diperoleh dengan mempertimbangkan kompartemen yang berperan dalam penyebaran penyakit, dalam hal ini adalah kelompok thinker dan adopter. mengacu pada persamaan (12) dan (13), serta memisalkan $x=(e, i)$ dan $\frac{d x}{d t}=F-V$, dengan.

$$
F=\left(\begin{array}{c}
\alpha(1-p-m)(1-\tau) s i-\rho e i \\
\alpha p(1-\tau) s i+\rho e i
\end{array}\right)
$$

dan

$$
\mathrm{V}=\left(\begin{array}{c}
(\epsilon+\theta) e \\
-\epsilon(1-\tau) e+\gamma \tau i+\theta i)
\end{array}\right)
$$


Selanjutnya, diperoleh $\boldsymbol{F}$ dan $\boldsymbol{V}$ yang masing-masing adalah matriks Jacobian dari $F$ dan $V$ saat sistem bebas rumor.

$$
\begin{gathered}
\boldsymbol{F}=\left(\begin{array}{cc}
0 & \frac{\alpha(1-p-m)(1-\tau) \pi}{\theta} \\
0 & \frac{\alpha p(1-\tau) \pi}{\theta}
\end{array}\right) \\
\boldsymbol{V}=\left(\begin{array}{cc}
\epsilon+\theta & 0 \\
-\epsilon(1-\tau) & \gamma \tau+\theta)
\end{array}\right)
\end{gathered}
$$

$\boldsymbol{F}$ adalah matriks laju individu terdampak sekunder dan $\boldsymbol{V}$ adalah matriks tingkat transmisi. Nilai $R_{o}$ ditentukan oleh nilai eigen dominan dari $\boldsymbol{F V}^{-1}$. Melalui perhitungan, diperoleh

$$
\boldsymbol{F} \boldsymbol{V}^{-1}=\left(\begin{array}{cc}
\frac{\alpha(1-p-m)(1-\tau)^{2 \frac{\pi}{\theta} \epsilon}}{(\epsilon+\theta)(\gamma \tau+\theta)} & \frac{\alpha(1-p-m)(1-\tau) \frac{\pi}{\theta}}{\gamma \tau+\theta} \\
\frac{\alpha p(1-\tau)^{2 \frac{\pi}{\mathrm{e}} \epsilon}}{(\epsilon+\theta)(\gamma \tau+\theta)} & \frac{\alpha p(1-\tau) \frac{\pi}{\theta}}{\gamma \tau+\theta}
\end{array}\right)
$$

Dikarenakan bentuk entri-entri matriks $\boldsymbol{F V}^{-1}$ yang cukup panjang, tidak mudah untuk menentukan nilai eigennya secara analitik. Oleh karena itu, proses perolehan nilai eigen dari $\boldsymbol{F} \boldsymbol{V}^{-1}$ juga dilakukan secara numerik.

Nilai $R_{o}$ yang diperoleh mengindikasikan seberapa viral suatu rumor dapat menyebar dalam jejaring sosial. Misalkan diperoleh $R_{o}=a>$ 1, artinya satu orang yang termakan rumor dapat menyebarkan rumor tersebut kepada sejumlah $a$ orang. Sedangkan untuk $R_{o}<1$, berarti satu orang yang termakan rumor menyebarkan kepada kurang dari satu orang lainnya. Dengan kata lain, apabila nilai $R_{o}<1$, maka jumlah orang yang termakan rumor akan terus menurun dan lama-kelamaan rumor akan hilang.

D. Simulasi Numerik

Pada bagian ini dibahas simulasi numerik dari model matematika yang dinyatakan oleh sistem (11)-(14). Melalui simulasi numerik dapat diketahui dinamika yang terjadi pada jejaring sosial daring saat terdapat rumor yang beredar. Nilai awal dari masing-masing variabel adalah $S_{o}=0.95, e_{o}=0, i_{o}=0.05, r_{o}=0$. Artinya, pada keadaan awal terdapat $5 \%$ dari total pengguna media sosial yang termakan oleh suatu rumor, dan 
95\% sisanya adalah pengguna media sosial yang belum mendengar rumor tersebut. Nilai-nilai parameter yang digunakan dalam simulasi disajikan dalam Tabel 1.

Tabel 1. Nilai Parameter dan Hasil Simulasi Numerik

\begin{tabular}{|c|c|c|c|c|c|c|}
\hline \multirow{2}{*}{ Parameter } & \multicolumn{6}{|c|}{ Skenario } \\
\hline & A & B & $\mathrm{C}$ & D & E & $\mathrm{F}$ \\
\hline$\pi$ & 0.4 & 0.4 & 0.4 & 0.4 & 0.4 & 0.4 \\
\hline$\alpha$ & 0.4 & 0.4 & 0.4 & 0.4 & 0.4 & 0.4 \\
\hline$\theta$ & 0.1 & 0.1 & 0.1 & 0.1 & 0.1 & 0.1 \\
\hline$\rho$ & 0.6 & 0.6 & 0.6 & 0.6 & 0.6 & 0.6 \\
\hline$\epsilon$ & 0.3 & 0.3 & 0.3 & 0.3 & 0.3 & 0.3 \\
\hline$p$ & 1 & 0.5 & 0.5 & 0.5 & 0 & 0 \\
\hline$m$ & 0 & 0.5 & 0 & 0.5 & 0.5 & 1 \\
\hline$\tau$ & 0 & 0 & 0.5 & 0.5 & 0.5 & 1 \\
\hline$\gamma$ & 0 & 0.2 & 0.2 & 0.2 & 0.2 & 0.2 \\
\hline $\begin{array}{c}\text { Titik } \\
\text { kesetimbangan } \\
\text { yang feasible }\end{array}$ & $E_{0}, E_{1}$ & $E_{0}, E_{1}$ & $E_{0}, E_{1}$ & $E_{0}, E_{1}$ & $E_{0}$ & $E_{0}$ \\
\hline $\begin{array}{c}\text { Titik } \\
\text { kesetimbangan } \\
\text { yang stabil }\end{array}$ & $E_{1}$ & $E_{1}$ & $E_{1}$ & $E_{1}$ & $E_{0}$ & $E_{0}$ \\
\hline$R_{0}$ & 16 & 8 & 2.75 & 2 & 0.75 & 0 \\
\hline
\end{tabular}


Terdapat enam skenario yang diterapkan dalam simulasi numerik. Skenario A dan B memberikan gambaran sistem apabila terdapat rumor, tetapi tidak diterapkan sikap tabayyun (ditandai oleh $\tau=0$ ). Skenario $\mathrm{C}$ dan $\mathrm{D}$ menggambarkan apabila terdapat rumor dan diterapkan sikap tabayyun. Sedangkan skenario D dan F menggambarkan keadaan jejaring sosial daring apabila peluang munculnya adopter baru adalah nol. Hasil simulasi numerik masing-masing skenario ditunjukkan oleh Gambar 5-7.

Gambar 5a adalah ilustrasi dari skenario A, diperoleh ketika $p=1, m=\tau=\gamma=0$. Artinya, probabilitas munculnya adopter adalah 100\%. Sedangkan proporsi user yang dapat menahan diri dari prasangka, tajassus dan ghibah adalah 0\%, probabilitas diterapkannya sikap tabayyun dalam menyikapi rumor adalah $0 \%$, dan recovery rate $0 \%$. Dalam Gambar 5a, terlihat bahwa populasi adopter terus meningkat seiring berjalannya waktu, sedangkan populasi non-adopter terus menurun. Sementara populasi thinker dan verifier tidak ada sejak awal sampai akhir. Hal inilah yang terjadi ketika tidak ada yang mencerminkan sikap kaum mukminin dalam menanggapi berita. Berdasarkan titik kesetimbangan endemik rumor $E_{1}=(0.25,0,3.75,0)$ yang bersifat stabil, diketahui bahwa pada akhirnya total pengguna media sosial meningkat menjadi empat kali lipat dari jumlah semula dan rumor yang dihembuskan akan terus ada dalam jejaring sosial. Dengan 93,75\% di antaranya sudah termakan rumor dan 6,25\% sisanya belum mendengar rumor. Pada skenario $\mathrm{A}$, diketahui nilai $R_{0}=16$, artinya satu orang yang termakan rumor dapat menyebarkan ke 16 orang yang lain.

(a) Populasi

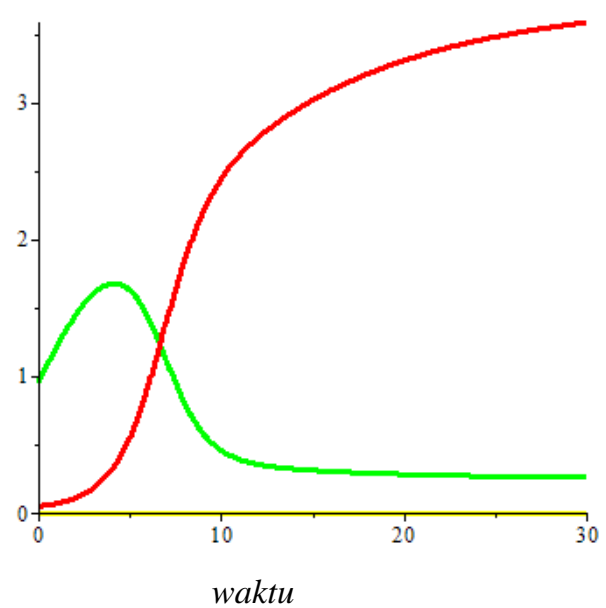

(b) Populasi

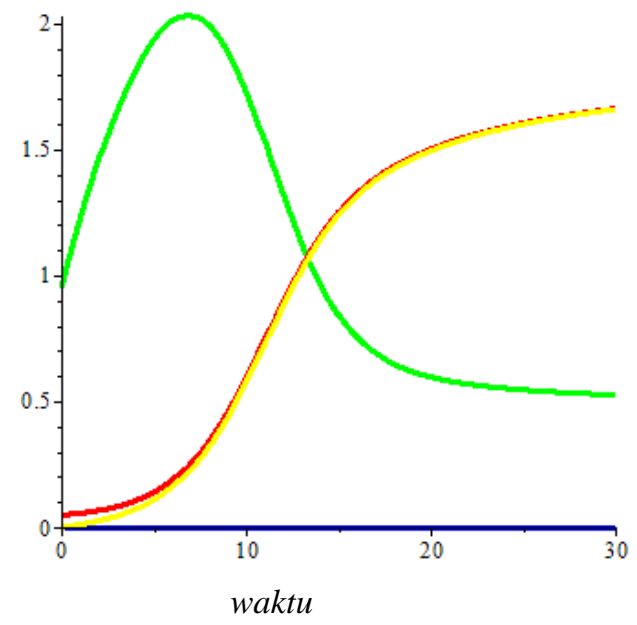




\section{Gambar 5. Dinamika Penyebaran Rumor dalam Jejaring Sosial Daring Tanpa Penerapan Sikap Tabayyun}

Dinamika yang terjadi dalam skenario B ditunjukkan oleh Gambar 5b. Gambar 5a dan 5b sama-sama mengilustrasikan sistem tanpa tabayyun. Perbedaan antara Gambar 5a dengan Gambar $5 \mathrm{~b}$ terletak pada nilai $p, m$ dan $\gamma$. Untuk skenario B digunakan $p=0.5, m=0.5$ dan $\gamma=$ 0.2. Artinya, probabilitas munculnya adopter adalah 50\%. Proporsi user yang dapat menahan diri dari prasangka, tajassus dan ghibah adalah $50 \%$ dan recovery rate $20 \%$. Serupa dengan Gambar 5a, tampak dalam Gambar 5b bahwa populasi non-adopter terus menurun seiring waktu, populasi adopter terus meningkat, dan tidak ada populasi thinker. Perbedaannya, dalam skenario B, seiring dengan meningkatnya adopter, jumlah populasi verifier juga ikut meningkat. Hal ini disebabkan masih adanya proporsi pengguna media sosial yang bisa menahan diri dari prasangka, tajassus dan ghibah, serta adanya recovery rate. Berdasarkan titik kesetimbangan endemik rumor $E_{1}=(0.5,0,1.75,1.75)$ yang bersifat stabil, diketahui bahwa pada akhirnya rumor yang dihembuskan akan terus ada dalam jejaring sosial, dengan 43,75\% dari total populasi termakan rumor, $43,75 \%$ terbebas dari rumor, dan $12,5 \%$ belum mendengar rumor. Nilai $R_{0}$ pada skenario B adalah 8 , artinya satu orang yang termakan rumor dapat menyebarkan ke 8 orang yang lain.

(c) Populasi

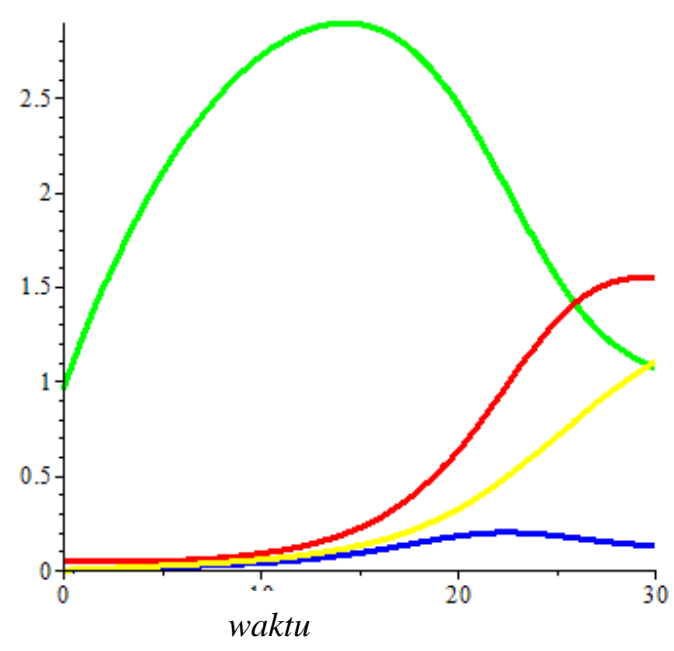

(b) Populasi

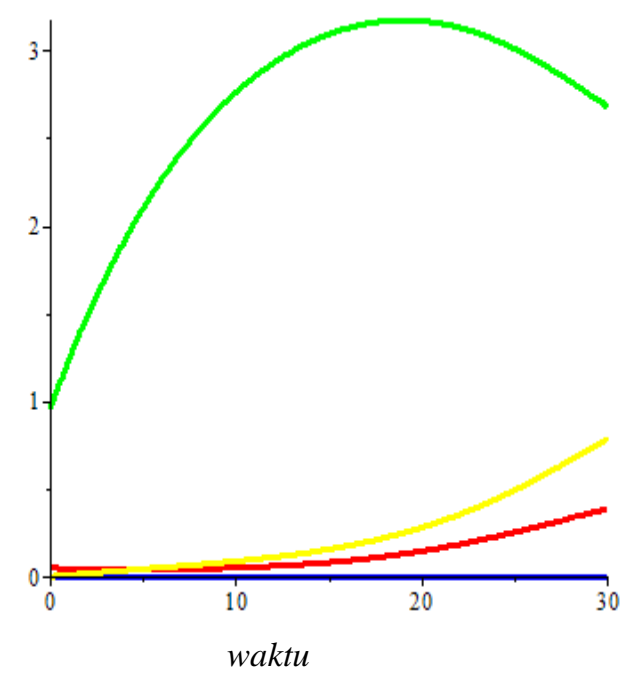

Non-adopter $\longrightarrow$ Thinker $\longrightarrow$ Adopter $=$ Verifier 


\section{Gambar 6. Dinamika Penyebaran Rumor dalam Jejaring Sosial Daring dengan Penerapan Sikap Tabayyun}

Gambar 6 menyajikan dinamika jumlah populasi dalam kelompok non-adopter, thinker, adopter, dan verifier ketika sikap tabayyun diterapkan apabila terdapat rumor yang beredar. Gambar 6a adalah ilustrasi dari skenario $C$, dengan nilai $p=0.5, m=0, \tau=0.5$. Artinya tidak ada user yang menahan diri dari prasangka, tajassus dan ghibah, dengan tingkat kemungkinan munculnya adopter adalah 50\% dan diterapkannya tabayyun 50\%. Melalui sifat kestabilan titik kesetimbangan endemik $E_{1}=(1.12,0.12,1.29,1.47)$, diketahui bahwa dinamika sistem stabil menuju titik $E_{1}$. Dengan kata lain, rumor akan terus ada, dengan proporsi 32,25\% termakan rumor, $3 \%$ masih berpikir tentang benar tidaknya rumor, $36,75 \%$ terbebas dari rumor dan $28 \%$ belum mendengar apa-apa. Dengan nilai $R_{0}=2.75$, diketahui bahwa dalam skenario C, satu orang yang termakan rumor dapat menyebarkan ke 2-3 orang lain, atau tepatnya empat orang adopter dapat menyebarkan ke 11 orang yang lain.

Gambar $6 \mathrm{~b}$ adalah ilustrasi dari skenario $\mathrm{D}$, dengan nilai $p=0.5, m=0.5, \tau=0.5$. Artinya, kemungkinan munculnya adopter, diterapkannya sikap tabayyun, dan kemampuan menahan diri dari prasangka, tajassus dan ghibah, bernilai 50\%. Berdasarkan kestabilan titik kesetimbangan endemik $E_{1}=(2,0,0.5,1.5)$, diketahui bahwa dinamika sistem stabil menuju proporsi populasi $12,5 \%$ termakan rumor, $37,5 \%$ terbebas dari rumor, $50 \%$ belum mendengar rumor. Dengan $R_{\mathrm{o}}=2$, diketahui bahwa dalam skenario $\mathrm{D}$, satu orang yang termakan rumor dapat menyebarkan ke 2 orang yang lain.

(e) Populasi

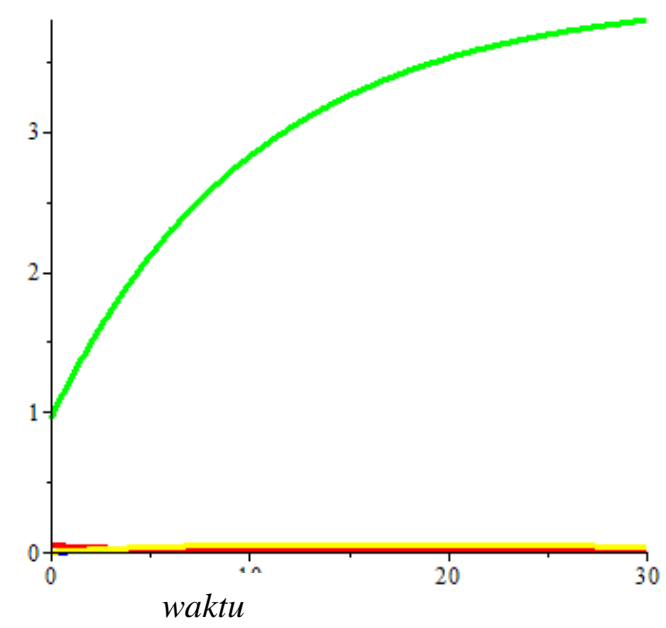

(b) Populasi

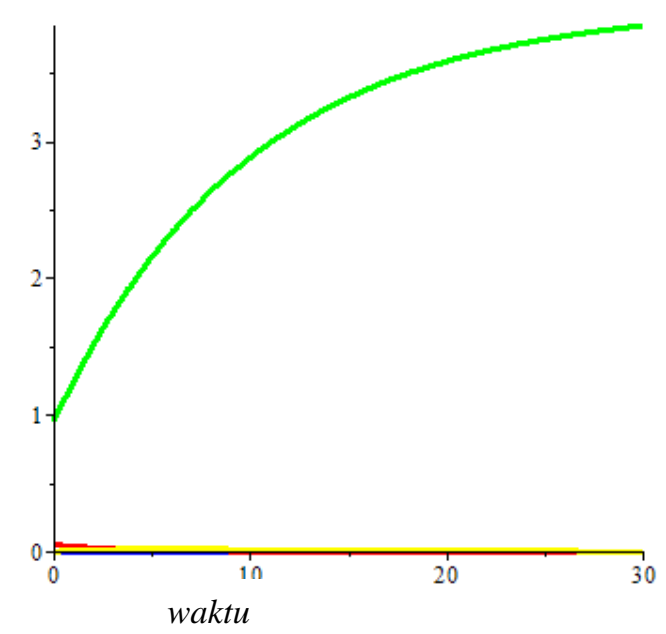

- Non-adopter $\longrightarrow$ Thinker $\longrightarrow$ Adopter $=$ Verifier 


\section{Gambar 7. Dinamika Penyebaran Rumor dalam Jejaring Sosial Daring dengan Penerapan Sikap Tabayyun dan Ketiadaan Adopter Baru}

Gambar 7a adalah ilustrasi dari skenario E, dengan nilai parameter $p=0, m=0.5, \tau=$ 0.5. Artinya, tidak ada adopter baru yang muncul dalam jejaring sosial daring. Dan probabilitas diterapkannya sikap tabayyuan serta kemampuan menahan diri dari prasangka, tajassus dan ghibah adalah 50\%. Dengan proporsi sikap tersebut, terlihat bahwa dari grafik bahwa populasi adopter berangsur turun dari 5\% menjadi nol, dan pada akhirnya semua user dalam jejaring sosial berstatus non-adopter. Hal ini terbaca pula dalam stabilnya titik kesetimbangan bebas rumor $E_{\mathrm{o}}=(4,0,0,0)$. Artinya, karena tidak ada lagi penghembus rumor dalam jejaring sosial daring, pada akhirnya populasi thinker, adopter, dan verifier adalah nol dan semua populasi masuk dalam kelompok non-adopter, dengan jumlah total empat kali lipat semula.

Gambar 7b menyajikan ilustrasi skenario F, dan ini adalah gambaran ideal sikap kaum mukminin dalam menanggapi berita yang beredar. Gambar $7 \mathrm{~b}$ diperoleh dengan menggunakan nilai $p=0, m=1$, dan $\tau=1$. Dengan kata lain, apabila terdapat suatu rumor dalam jejaring sosial daring, tidak ada adopter baru yang muncul, semua user menerapkan sikap tabayyun, dan dapat menahan diri dari prasangka, tajassus dan ghibah. Apabila hal ini diterapkan, hasilnya serupa dengan Gambar 7a, dinamika populasi stabil menuju titik kesetimbangan bebas rumor $E_{\mathrm{o}}$ $=(4,0,0,0)$. Tidak ada lagi rumor dan tidak ada populasi thinker, adopter, dan verifier. Semua populasi masuk dalam kelompok non-adopter dengan jumlah total empat kali lipat semula. Perbedaan antara Gambar 7a dan 7b terletak pada waktu yang diperlukan untuk mencapai keadaan setimbang bebas rumor. Dari perbandingan kedua gambar, terlihat bahwa waktu yang diperlukan untuk bebas rumor pada skenario F lebih cepat dari skenario E.

Tabel 2. Perbandingan Proporsi Populasi dalam Jejaring Sosial Daring

\begin{tabular}{|c|c|}
\hline & Skenario \\
\hline
\end{tabular}




\begin{tabular}{|c|c|c|c|c|c|c|}
\cline { 2 - 7 } & $\mathrm{A}(p=$ & $\mathrm{B}$ & $\mathrm{C}$ & $\mathrm{D}$ & $\mathrm{E}$ & $\mathrm{F}$ \\
& 1, & $(p=0.5$, & $(p=0.5$, & $(p=0.5$, & $(p=0$, & $(p=0$, \\
& $m=0$, & $m=0.5$, & $m=0$, & $m=0.5$, & $m=0.5$, & $m=1$, \\
& $\tau=0)$ & $\tau=0)$ & $\tau=0.5)$ & $\tau=0.5)$ & $\tau=0.5)$ & $\tau=1)$ \\
\hline Non-adopter & $6,25 \%$ & $12,5 \%$ & $28 \%$ & $50 \%$ & $100 \%$ & $100 \%$ \\
\hline Thinker & - & - & $3 \%$ & - & - & - \\
\hline Adopter & $93,75 \%$ & $43,75 \%$ & $32,25 \%$ & $12,5 \%$ & - & - \\
\hline Verifier & - & $43,75 \%$ & $36,75 \%$ & $37,5 \%$ & - & - \\
\hline
\end{tabular}

Perbandingan proporsi populasi dalam jejaring sosial daring pada skenario A-F ditunjukkan oleh Tabel 2. Berdasarkan Tabel 2, diketahui bahwa skenario A memiliki proporsi adopter paling tinggi, skenario B memiliki proporsi verifier tertinggi sedangkan skenario E dan F sepenuhnya bisa terlindung dari rumor.

\section{E. PENUTUP}

\section{Simpulan}

Berdasarkan hasil dan pembahasan, diketahui bahwa sikap tabayyun yang diterapkan dalam menyikapi berita yang beredar di jejaring sosial daring mampu mengurangi penyebaran rumor. Selain tabayyun, sikap menahan diri dari prasangka, tajassus, dan ghibah juga berperan dalam menekan penyebaran rumor dalam model. Semakin banyak orang yang menahan diri dari prasangka, tajassus, ghibah, serta menerapkan sikap tabayyun, maka semakin cepat suatu rumor dapat dihalau. Dengan menerapkan kedua sikap tersebut, yang merupakan cerminan sikap kaum mukminin, pengguna media sosial dapat terlindungi dari berita yang tidak jelas kebenarannya

\section{Saran}

Model yang dikonstruksi dalam penelitian ini mengasumsikan bahwa rumor hanya beredar di lingkup jejaring sosial daring dan berefek pada pengguna media sosial saja. Pada kenyataannya, penyebaran rumor tentu lebih kompleks dari yang diasumsikan. Misalnya, suatu rumor dalam jejaring sosial daring juga bisa menyebar ke luring dan berefek pada masyarakat yang bukan pengguna media sosial. Oleh karenanya, pengembangan model dengan asumsi yang lebih realistis dimungkinkan untuk memperoleh hasil yang lebih relevan dengan kenyataan. 


\section{DAFTAR PUSTAKA}

Adhiarso, D. S., P. Utari dan Y. Slame. "Pemberitaan Hoax di Media Online Ditinjau dari Konstruksi Berita dan Respon Netizen.” Jurnal Ilmu Komunikasi, Vol. 15, No. 3 (2017), 215-225.

Dhar, J., A. Jain dan V. K. Gupta. “A Mathematical Model of News Propagation on Online Social Network and A Control Strategy for Rumor Spreading." Social Network Analysis and Mining, Vol. 6, No. 57 (2016), 1-9.

Hu, Y., Q. Pan, W. Huo, dan M. He. "Rumor Spreading Model Considering The Proportion of Wisemen in The Crowd." Physica A: Statistical Mechanics and Its Applications, Vol. 505 (2018), 1084-1094.

Ningsih, W., Sumardi, I. R. Riskiyah, dan D. P. Arystianto. "Kendali Optimal Model Matematika Penyebaran Rumor pada Jaringan Sosial Daring dengan Pemberian Pernyataan Balasan.” Prosiding Seminar Nasional Integrasi Matematika dan Nilai Islami, Vol. 3, No. 1 (September 2019), 17-27.

Xia, L. L., G. P. Jiang, B. Song dan Y. R. Song. "Rumor Spreading Model Considering Hesitating Mechanism in Complex Social Networks." Physica A: Statistical Mechanics and Its Applications, Vol. 437 (2015), 295-303.

Zhu L., dan Y. Wang. "Rumor Spreading Model With Noise Interference in Complex Social Network.” Physica A: Statistical Mechanics and Its Applications, Vol. 469, (2017), 750760. 